\title{
IMPLEMENTASI SIMPLE ADDITIVE WEIGHTING DAN WEIGHTED PRODUCT PADA SISTEM PENDUKUNG KEPUTUSAN UNTUK REKOMENDASI PENERIMA BERAS SEJAHTERA
}

\author{
Berlilana $^{1}$, Fandhi Dhuga Prayoga ${ }^{2}$, Fandy Setyo Utomo ${ }^{3}$ \\ 1,2,3 Program Studi Sistem Informasi, STMIK AMIKOM Purwokerto \\ Email: ${ }^{1}$ berli@amikompurwokerto.ac.id, ${ }^{2}$ fduga2@gmail.com, ${ }^{3}$ fandy_setyo_utomo@amikompurwokerto.ac.id
}

(Naskah masuk: 11 April 2018, diterima untuk diterbitkan: 28 Agustus 2018)

\begin{abstract}
Abstrak
Salah satu upaya pemerintah untuk mengatasi masalah kemiskinan di Indonesia yaitu membuat program beras sejahtera (RASTRA). RASTRA merupakan program dari pemerintah berupa bantuan beras bersubsidi untuk membantu masyarakat yang berpenghasilan rendah. Permasalahan yang terjadi yakni banyaknya kriteria penilaian yang digunakan dalam pedoman RASTRA dan penduduk miskin di suatu area/wilayah seringkali menyulitkan proses penentuan Keluarga Penerima Manfaat yang berhak menerima RASTRA pada Musyawarah desa/kecamatan. Tujuan penelitian ini adalah merancang dan mengembangkan sistem penunjang keputusan menggunakan model Simple Additive Weighting (SAW) dan Weighted Product (WP) untuk memberikan rekomendasi penerima RASTRA. Penelitian ini menggunakan beberapa tahapan yang terdiri dari analisis kebutuhan perangkat lunak, desain perangkat lunak, pengembangan, dan pengujian perangkat lunak. Hasil penelitian ini berupa aplikasi berbasis desktop dengan model SAW dan WP untuk memberikan rekomendasi penerima Beras Sejahtera. Berdasarkan hasil pengujian, hasil perhitungan nilai preferensi SAW memiliki performa yang lebih baik daripada WP karena SAW mampu meminimalisir nilai preferensi alternatif yang sama. Hal ini tampak dari perankingan alternatif berdasarkan hasil perhitungan SAW sejumlah 13 peringkat, dan WP sejumlah 10 peringkat.
\end{abstract}

Kata kunci: Sistem Pendukung Keputusan, Simple Additive Weighting, Weighted Product, Multi-attribute Decision Making

\section{IMPLEMENTATION OF SIMPLE ADDITIVE WEIGHTING AND WEIGHTED PRODUCT IN DECISION SUPPORT SYSTEM FOR RECEIVER "BERAS SEJAHTERA" RECOMMENDATIONS}

\begin{abstract}
One of the government's efforts to overcome the poverty problem in Indonesia is to make the program "Beras Sejahtera" (RASTRA). RASTRA is a government program of subsidised rice to help low-income communities. The problems which occur are the number of assessment criteria used in the RASTRA guidelines and the poor in an area/region often complicate the process of determining the Beneficiary Family who are eligible to receive RASTRA at the village/sub-district deliberation. The purpose of this research is to design and develop decision support system using Simple Additive Weighting (SAW) and Weighted Product (WP) model to give the recommendation of RASTRA recipient. This study uses several stages consisting of software requirements analysis, software design, development, and software testing. The results of this study are desktop-based applications with SAW and WP models to provide recipients recommendations of Beras Sejahtera. Based on the test results, the calculation of SAW preference values has better performance than WP because SAW can minimise the value of the same alternative preferences. This can be seen from the alternative ranking based on the calculation of SAW of 13 ranks, and WP 10 rank number.
\end{abstract}

Keywords: Decision Support System, Simple Additive Weighting, Weighted Product, Multi-attribute Decision Making 


\section{PENDAHULUAN}

Indonesia merupakan salah satu negara berkembang yang sedang berbenah dan berusaha untuk membangun sektor ekonomi, politik, sosial, dan lain-lain. Masalah yang menjadi perhatian dalam bidang ekonomi yakni karena adanya peningkatan jumlah penduduk miskin di Indonesia. Berdasarkan informasi dari Badan Pusat Statistik (BPS) di bulan Maret 2017, total masyarakat miskin di Indonesia berjumlah 27,77 juta orang (10,64 persen), bertambah hingga 6,90 ribu orang dibandingkan dengan keadaan pada bulan September 2016 sejumlah 27,76 juta orang (10,70 persen).

Konsep masyarakat miskin menurut BPS yakni masyarakat yang mempunyai rata-rata pembelanjaan perkapita perbulan dibawah garis kemiskinan. Salah satu upaya pemerintah untuk mengatasi masalah kemiskinan yaitu membuat program beras miskin (Raskin) sekarang disebut beras sejahtera (Rastra). Rastra merupakan program dari pemerintah berupa bantuan beras bersubsidi untuk membantu masyarakat yang berpenghasilan rendah.

Berdasarkan Pedoman Umum Subsidi Rastra tahun 2017, telah ditentukan cara merubah data Keluarga Penerima Manfaat (KPM) agar tepat sasaran dan terbarui, yaitu dengan mengubah Daftar Penerima Manfaat (DPM) melalui validasi KPM oleh musyawarah desa/kelurahan untuk menghasilkan KPM Rastra mutakhir yang nantinya akan dituangkan di dalam DPM. Kriteria keluarga yang dikatakan layak untuk menggantikan KPM diutamakan kepada keluarga tidak mampu yang mempunyai anggota rumah tangga lebih besar, terdiri dari: anak usia di bawah lima tahun dan anak usia sekolah, kepala keluarganya perempuan, kondisi bangunan rumahnya tidak layak ditempati, serta berpendapatan paling kecil dan tidak tetap.

Proses pemutakhiran data KPM dapat dilakukan sepanjang tahun berjalan sesuai dengan kebutuhan dengan cara mengadakan musyawarah desa atau musyawarah kecamatan yang dihadiri oleh kepala desa, ketua Rukun Tetangga (RT), ketua rukun warga $(\mathrm{RW})$, Badan Permusyawaratan Desa (BPD), dan tokoh-tokoh masyarakat serta perwakilan KPM Rastra dari setiap Satuan Lingkungan Setempat (SLS) setingkat dusun/RW. Permasalahan yang terjadi yakni banyaknya kriteria penilaian yang digunakan dalam pedoman Rastra dan penduduk miskin di suatu area/wilayah seringkali menyulitkan proses penentuan KPM pada Musyawarah desa/kecamatan.

Permasalahan yang timbul dapat diselesaikan dengan menerapkan sistem pendukung keputusan (SPK) dalam memberikan rekomendasi kelayakan penerima Rastra yang dapat dijadikan rujukan dan pegangan untuk melakukan pemutakhiran data DPM dengan lebih objektif pada Musyawarah desa/kecamatan. SPK akan memvisualisasikan ukuran-ukuran skala rasio yang lebih pasti dengan proses matematis. Multi-attribute Decision Making (MADM) merupakan salah satu metode sistem pendukung keputusan yang dapat digunakan untuk menyelesaikan permasalahan. MADM memberikan rekomendasi berdasarkan hasil evaluasi dan perankingan terhadap sejumlah set alternatif dan kriteria penilaian (Biswas, dkk., 2015; Ding, dkk, 2016). Simple Additive Weighting (SAW) dan Weighted Product (WP) merupakan pendekatan MADM yang dapat diadopsi untuk menyelesaikan permasalahan rekomendasi penerima Rastra (Handayani, 2017a; Handayani, 2017b). Tujuan penelitian ini adalah merancang dan mengembangkan aplikasi sistem pendukung keputusan menggunakan model SAW dan WP untuk memberikan rekomendasi penerima Rastra.

\section{SIMPLE ADDITIVE WEIGHTING}

Simple Additive Weighting merupakan model penjumlahan berbobot. Pendekatan SAW yakni mencari penjumlahan terbobot dari rating kinerja seluruh alternatif pilihan pada semua atribut (Wulandari, dkk, 2016; Hasugian, dkk, 2017; Ramadhani, dkk, 2018). Model SAW membutuhkan operasi normalisasi matriks keputusan ke suatu ukuran yang dapat dikomparasi dengan rating keseluruhan alternatif (Muslihudin \& Arumita, 2016; Hidayat \& Baihaqi, 2016). SAW memiliki dua atribut, yaitu atribut keuntungan (benefit) dan biaya (cost). Persamaan (1) merupakan rumus model SAW (Batu \& Fibriani, 2017; Wati \& Mayasari, 2015; Khairul, dkk, 2016).

$r_{i j}=\left\{\begin{array}{c}\frac{x_{i j}}{\operatorname{Max}_{i} x_{i j}} \text { (Jika atribut Benefit) } \\ \frac{\operatorname{Min}_{i} x_{i j}}{x_{i j}} \text { (Jika atribut Cost) }\end{array}\right.$

Pada Persamaan (1), $\mathrm{r}_{\mathrm{ij}}$ merupakan rating kinerja ternormalisasi dari alternatif $\mathrm{Ai}$ pada atribut $\mathrm{Cj}, \mathrm{i}=1$, 2, ..., m; dan j=1, 2, ..., n. Persamaan (2) menjelaskan rumus untuk menentukan nilai Preferensi tiap alternatif $\left(\mathrm{V}_{\mathrm{i}}\right)$.

$V_{i}=\sum_{j=1}^{n} W_{j} R_{i j}$

Pada Persamaan (2), $\mathrm{W}_{\mathrm{j}}$ merupakan bobot yang telah ditentukan; sedangkan $\mathrm{R}_{\mathrm{ij}}$ adalah normalisasi matriks.

\section{WEIGHTED PRODUCT}

Pendekatan Weighted Product memanfaatkan perkalian untuk mengkorelasikan rating atribut. Rating tiap atribut dipangkatkan terlebih dahulu dengan bobot yang bersangkutan (Mulyani, dkk, 2016; Pandean \& Hansun, 2018; Ramadhan, dkk, 2016; Siagian, dkk, 2017). Proses tersebut sama dengan proses normalisasi. Persamaan 
merupakan model guna menentukan nilai preferensi untuk alternatif Ai (Ahmadi \& Wiyanti, 2014; Divayana, dkk, 2017).

$S_{i}=\prod_{j=1}^{n} X_{i j}^{W_{j}}$

Pada Persamaan (3), i=1, 2, ..., m; $x$ menyatakan nilai kriteria, $w$ menyatakan bobot kriteria, $n$ menunjukkan jumlah kriteria. $\mathrm{W}_{\mathrm{j}}$ berpangkat positif untuk atribut keuntungan dan berpangkat negatif untuk atribut biaya.

\section{METODE PENELITIAN}

Terdapat empat tahapan dalam menyelesaikan penelitian ini, yaitu tahap analisis kebutuhan perangkat lunak, desain perangkat lunak, pengembangan perangkat lunak, dan pengujian perangkat lunak. Studi kasus penelitian ini dilakukan di desa Babakan, Kecamatan Karanglewas, Kabupaten Banyumas. Keempat tahapan penelitian tersebut dapat dijabarkan sebagai berikut:

\section{A. Analisis Kebutuhan Perangkat Lunak}

Analisis kebutuhan perangkat lunak dilakukan dengan cara mengidentifikasi kebutuhan fungsional dan non-fungsional perangkat lunak. Kebutuhan fungsional terdiri dari kebutuhan masukan, kebutuhan pemrosesan, dan kebutuhan keluaran. Identifikasi kebutuhan fungsional dilakukan dengan mewawancarai pihak pengurus desa Babakan, melakukan observasi terhadap proses penetapan KPM Rastra, dan mengumpulkan dokumentasi terkait program Rastra.

\section{B. Desain Perangkat Lunak}

Setelah fase analisis usai, hasil identifikasi kebutuhan fungsional diimplementasikan ke dalam bentuk desain perangkat lunak. Pada penelitian ini, desain perangkat lunak menggunakan diagram konteks, Data Flow Diagram (DFD), Entity Relationship Diagram (ERD), rancangan struktur tabel dan relasi antar tabel, serta rancangan antarmuka pengguna.

\section{Pengembangan Perangkat Lunak}

Pada fase ini dilakukan pembuatan sistem pendukung keputusan dengan mengintegrasikan model Simple Additive Weighting dan Weighted Product ke dalam aplikasi. Aplikasi dibuat berdasarkan desain perangkat lunak yang telah usai dibuat. Microsoft SQL Server digunakan sebagai database, sedangkan Visual Studio .NET digunakan untuk membuat antarmuka aplikasi.

\section{Pengujian Perangkat Lunak}

Pengujian fungsional perangkat lunak atau yang dikenal sebagai pengujian Blackbox digunakan dalam penelitian ini untuk menguji seluruh fitur aplikasi. Apabila ditemukan fitur yang belum mampu berfungsi dengan baik, maka akan dilakukan perbaikan terhadap fitur tersebut. Tabel 1 menunjukkan rencana pengujian Blackbox yang diimplementasikan di dalam penelitian ini.

\begin{tabular}{|c|c|c|c|}
\hline No & Hak akses & Kelas uji & Butir uji \\
\hline 1 & Admin & Login & Verifikasi data \\
\hline 2 & Admin & $\begin{array}{l}\text { Data } \\
\text { alternatif }\end{array}$ & $\begin{array}{l}\text { - } \text { Tambah data } \\
\text { - Ubah data } \\
\text { - Hapus data }\end{array}$ \\
\hline 3 & Admin & $\begin{array}{l}\text { Data } \\
\text { kriteria }\end{array}$ & $\begin{array}{l}\text { - } \text { Tambah data } \\
\text { - Ubah data } \\
\text { - } \text { Hapus data }\end{array}$ \\
\hline 4 & Admin & Data nilai & $\begin{array}{l}\text { - Tambah data } \\
\text { - Ubah data }\end{array}$ \\
\hline 5 & Admin & Kata sandi & Ubah kata sandi \\
\hline
\end{tabular}

\section{HASIL DAN PEMBAHASAN}

Bagian 5.1 membahas tentang desain perangkat lunak berdasarkan output dari fase analisis kebutuhan perangkat lunak. Selanjutnya, bagian 5.2 membahas tentang antarmuka dan fitur aplikasi, serta pengujian perangkat lunak. Pengujian perangkat lunak mencakup pengujian Blackbox, serta skenario pengujian Simple Additive Weighting dan Weighted Product.

\subsection{Desain Perangkat Lunak}

Berdasarkan hasil analisis kebutuhan perangkat lunak, terdapat beberapa kebutuhan input pengguna, yakni input alternatif, kriteria, dan nilai rating kecocokan tiap alternatif untuk seluruh kriteria. Selanjutnya, kebutuhan output pengguna dari aplikasi yaitu laporan hasil perankingan alternatif dengan metode Simple Additive Weighting dan Weighted Product. Gambar 1 menunjukkan Diagram Konteks yang dibuat berdasarkan hasil analisis kebutuhan input dan output.

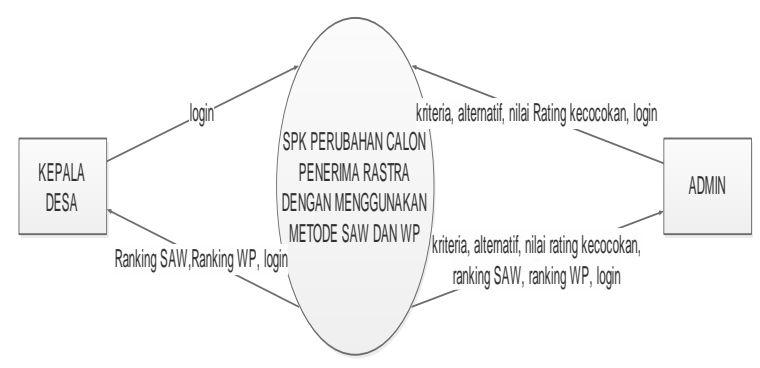

Gambar 1. Diagram Konteks

Berdasarkan Gambar 1, terdapat dua entitas eksternal yang akan berinteraksi dengan sistem pendukung keputusan secara langsung, yaitu Kepala Desa dan Administrator aplikasi. Administrator aplikasi yakni staf kantor desa yang ditunjuk untuk mengelola aplikasi.

Dekomposisi diagram konteks ke bentuk Diagram level 0 bertujuan untuk mengidentifikasi tempat simpanan data (storage), kebutuhan proses, 
dan secara spesifik mengidentifikasi alur data. Gambar 2 menjelaskan diagram level 0 sistem pendukung keputusan. Berdasarkan penjelasan pada Gambar 2, terdapat lima kebutuhan proses utama di dalam sistem, yakni proses pengelolaan alternatif, pengelolaan kriteria, rating kecocokan, perhitungan SAW dan WP, serta pemrosesan akses ke dalam aplikasi.

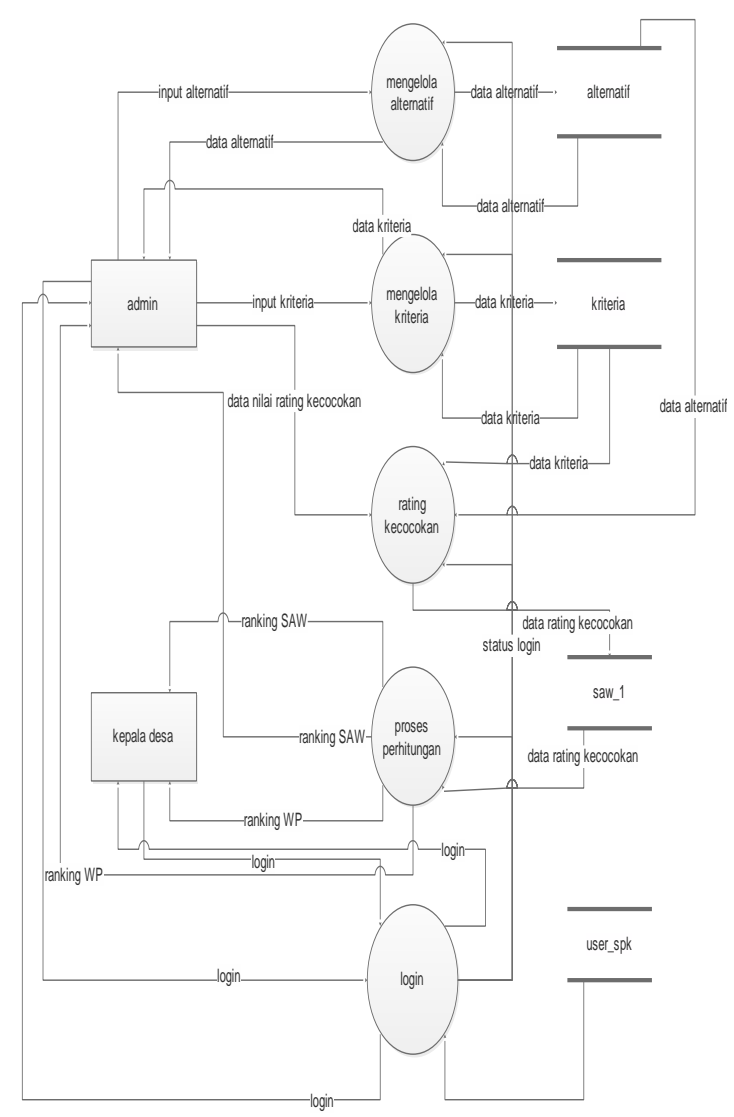

Gambar 2. Diagram Level 0

Selanjutnya, desain DFD Level 0 diterjemahkan ke dalam bentuk ERD. Berdasarkan DFD tersebut pada Gambar 2, terdapat empat simpanan data yang teridentifikasi, yaitu alternatif, kriteria, saw_1, dan user_spk. Keempat simpanan data tersebut mutlak disertakan dalam desain ERD dalam bentuk entitas. Gambar 3 menjelaskan ERD di dalam penelitian ini. Seperti yang ditunjukkan pada Gambar 3, ERD terdiri dari 13 entitas, termasuk di dalamnya empat entitas yang berasal dari simpanan data pada DFD Level 0. Atribut yang dimiliki oleh entitas user_spk telah dijabarkan pada Gambar 3, sedangkan atribut yang dimiliki oleh keduabelas entitas lainnya dapat dijabarkan sebagai berikut, (1) Entitas saw_2: id_alternatif, id_kriteria, bobot_kriteria, tahun, jenis_kriteria, hasil; (2) Entitas saw_akhir: id_alternatif, hasil; (3) Entitas saw_laporan: id_alternatif, hasil, tahun, peringkat, nama_alternatif; (4) Entitas $\boldsymbol{w} p \_b o b o t: ~ i d \_k r i t e r i a$, bobot, tahun, jenis_kriteria; (5) Entitas saw_1: id_alternatif, id_kriteria, bobot_kriteria, tahun, jenis_kriteria, nilai, id; (6) Entitas alternatif: id alternatif, attribute; (7) Entitas kriteria: id_kriteria, nama_kriteria, jenis_kriteria, bobot_kriteria, keterangan_kriteria; (8) Entitas wp_bobot_fix: id_kriteria, bobot, fix_bobot, tahun, jenis_kriteria; (9) Entitas $\boldsymbol{w p} \_\mathbf{1}$ : id_alternatif, id_kriteria, bobot_kriteria, tahun, jenis_kriteria, nilai, hasil_pangkat; (10) Entitas $\boldsymbol{w p}$ 2: id_alternatif, tahun, vektor_s; (11) Entitas $\boldsymbol{w p} \_\boldsymbol{a k h i r}$ : id_alternatif, hasil_akhir, vektor_s; dan (12) Entitas $\boldsymbol{w p}$ _laporan: id_alternatif, hasil_akhir, tahun, peringkat, nama_alternatif.

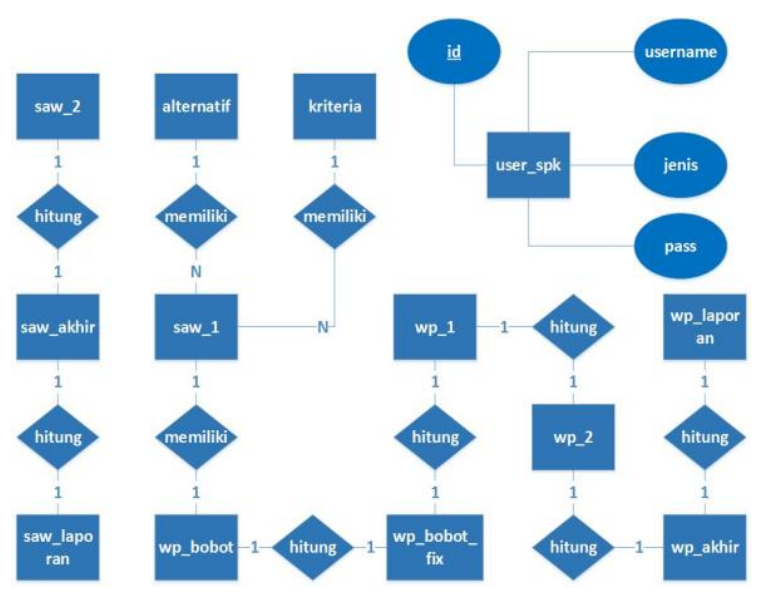

Gambar 3. Entity Relationship Diagram

\subsection{Implementasi dan Pengujian Perangkat Lunak}

Pada tahap implementasi perangkat lunak, kami mengembangkan basis data pada Microsoft SQL Server berdasarkan rancangan struktur tabel dan relasi antar tabel yang telah dibuat pada fase desain perangkat lunak. Selain itu, kami juga mengembangkan antarmuka aplikasi menggunakan perangkat Visual Studio .NET. Gambar 4 menunjukkan halaman menu utama aplikasi.

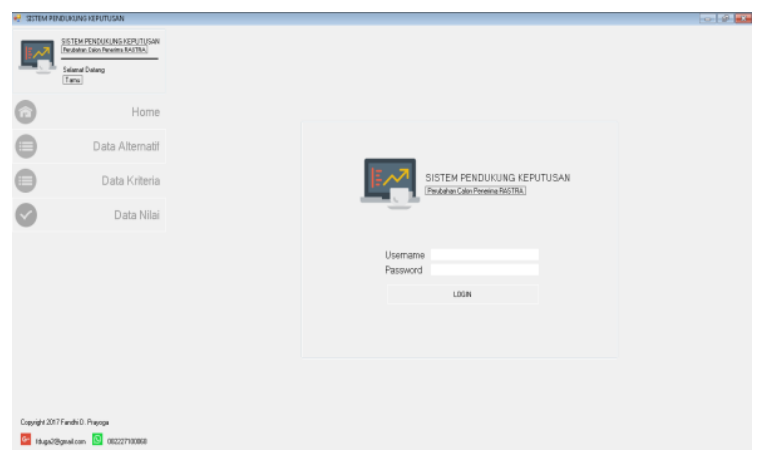

Gambar 4. Antarmuka Halaman Utama Aplikasi

Terdapat empat menu utama aplikasi, yaitu menu home digunakan untuk menampilkan antarmuka halaman utama aplikasi, menu Data Alternatif berfungsi untuk menampilkan antarmuka alternatif, 
menu Data Kriteria berfungsi untuk menampilkan antarmuka kriteria, dan menu Data Nilai berfungsi untuk menampilkan antarmuka input nilai dan hasil proses perhitungan SAW/WP.

Gambar 5 mendeskripsikan fitur pengolahan data kriteria. Pada fitur tersebut, tiap kriteria ditentukan tipenya, termasuk atribut keuntungan (benefit) atau biaya (cost). Selain itu, tiap kriteria ditentukan pula bobotnya masing-masing.

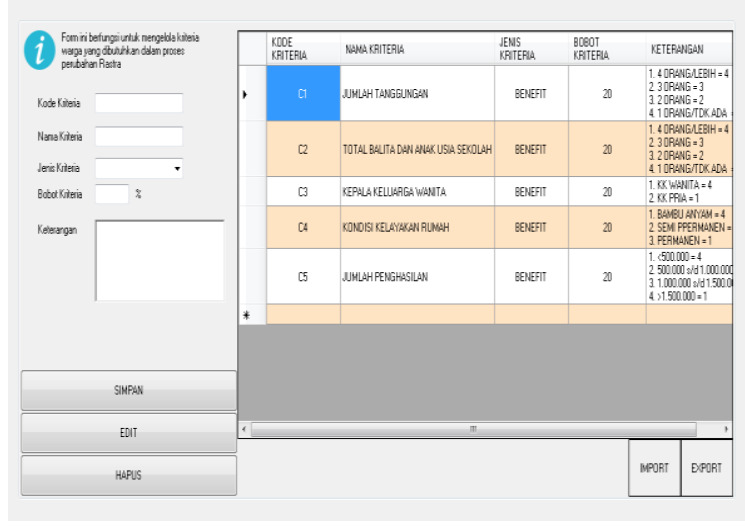

Gambar 5. Antarmuka Pengelolaan Data Kriteria

Selanjutnya, Gambar 6 menunjukkan antarmuka fitur tabulasi input nilai setiap alternatif untuk seluruh kriteria penilaian. Panel bagian kiri menunjukkan daftar alternatif, sedangkan panel bagian kanan menunjukkan kriteria atau atribut penilaian dan nilainya.

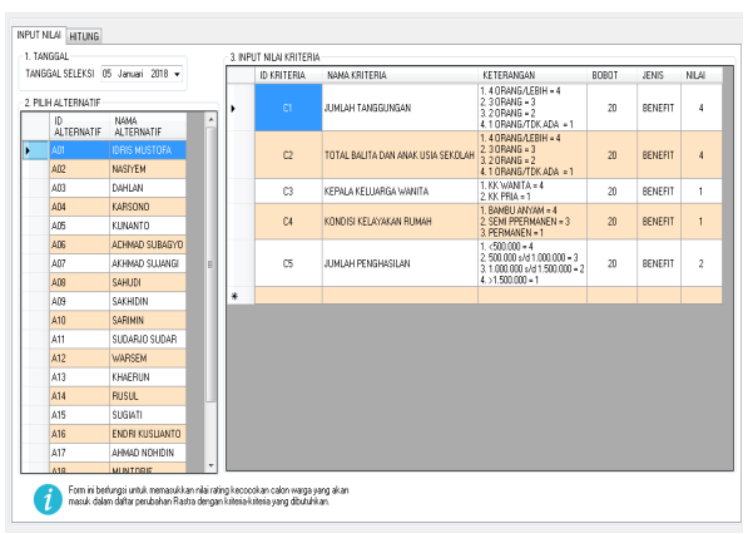

Gambar 6. Antarmuka Pengelolaan Nilai

Berikutnya, Gambar 7 menunjukkan antarmuka fitur tabulasi hasil perhitungan SAW dan WP. Kami juga menyediakan fitur untuk mencetak atau menyimpan hasil kedua perhitungan model tersebut.

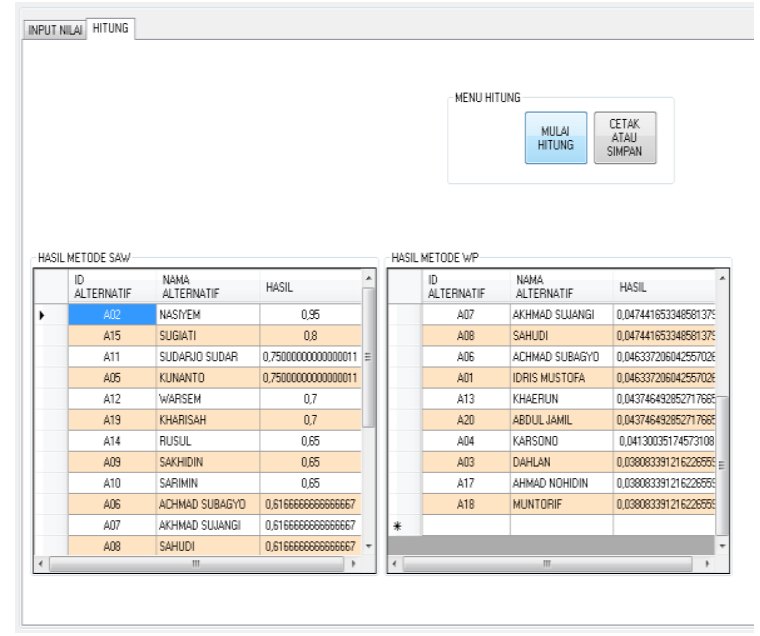

Gambar 7. Antarmuka Tabulasi Hitung

Setelah tahap pengembangan perangkat lunak usai, dilakukan pengujian terhadap seluruh fitur aplikasi menggunakan pengujian Blackbox. Uji kasus yang dikembangkan untuk melakukan pengujian Blackbox, kami buat dengan kasus benar dan kasus salah. Berdasarkan hasil pengujian Blackbox, sesuai dengan rencana pengujian pada Tabel 1, diperoleh hasil bahwa seluruh fitur aplikasi dapat berfungsi dengan baik.

Berdasarkan data yang diperoleh dari kantor kepala desa, terdapat 1208 kepala keluarga di desa babakan. Jumlah alternatif yang dijadikan sampel pada skenario perhitungan SAW dan WP berjumlah 20 kepala keluarga. Jumlah alternatif tersebut ditentukan berdasarkan aturan SLOVIN. Tabel 2 menjelaskan alternatif yang digunakan pada perhitungan.

\begin{tabular}{cl} 
& Tabel 2. Daftar Alternatif \\
\hline ALTERNATIF & \multicolumn{1}{c}{ NAMA } \\
\hline A1 & IDRIS MUSTOFA \\
A2 & NASIYEM \\
A3 & DAHLAN \\
A4 & KARSONO \\
A5 & KUNANTO \\
A6 & ACHMAD SUBAGYO \\
A7 & AKHMAD SUJANGI \\
A8 & SAHUDI \\
A9 & SAKHIDIN \\
A10 & SARIMIN \\
A11 & SUDARJO SUDAR \\
A12 & WARSEM \\
A13 & KHAERUN \\
A14 & RUSUL \\
A15 & SUGIATI \\
A16 & ENDRI KUSLIANTO \\
A17 & AHMAD NOHIDIN \\
A18 & MUNTORIF \\
A19 & KHARISAH \\
A20 & ABDUL JAMIL \\
\hline
\end{tabular}

Langkah selanjutnya yaitu menentukan kriteria yang akan dijadikan acuan dalam pengambilan keputusan. Berdasarkan buku panduan Rastra dan Kepala Desa, penerima Rastra dapat direvisi melalui musyawarah desa berdasarkan beberapa kriteria, yaitu jumlah 
tanggungan (C1), total balita dan anak usia sekolah (C2), kepala keluarga wanita (C3), kondisi kelayakan rumah (C4), dan jumlah penghasilan (C5).

Setelah kriteria penilaian ditentukan, selanjutnya setiap kriteria diberikan bobot. Bobot tiap kriteria ditentukan berdasarkan hasil wawancara penulis dengan pengurus desa Babakan yang berada di kecamatan Karanglewas, kabupaten Banyumas yang telah dipilih sebagai lokasi penelitian. Tabel 3 menjelaskan bobot kriteria jumlah tanggungan, total balita, dan anak usia sekolah. Berikutnya, Tabel 4 menjelaskan bobot kriteria kepala keluarga, sedangkan Tabel 5 menjelaskan bobot kriteria kondisi rumah. Terakhir, Tabel 6 menjelaskan bobot kriteria jumlah penghasilan.

Tabel 3. Bobot Kriteria Jumlah tanggungan, Total Balita, dan

\begin{tabular}{lc}
\multicolumn{2}{c}{ Anak Usia Sekolah } \\
\hline \multicolumn{1}{c}{ Jumlah Tanggungan } & Bobot \\
\hline 4 orang atau lebih & 4 \\
3 orang & 3 \\
2 orang & 2 \\
1 orang atau tidak punya & 1 \\
\hline
\end{tabular}

\begin{tabular}{|c|c|}
\hline Kepala Keluarga & Bobot \\
\hline Kepala Keluarga Wanita & 4 \\
\hline Kepala Keluarga Laki-Laki & 1 \\
\hline
\end{tabular}

Tabel 5. Bobot Kriteria Kondisi Rumah

\begin{tabular}{lc}
\hline \multicolumn{1}{c}{ Kondisi Rumah } & Bobot \\
\hline Bambu anyam & 4 \\
Semi permanen & 3 \\
permanen & 1 \\
\hline
\end{tabular}

Tabel 6. Bobot Kriteria Jumlah Penghasilan

\begin{tabular}{lc}
\hline \multicolumn{1}{c}{ Jumlah Penghasilan } & Bobot \\
\hline$<500.000$ & 4 \\
$500.000 \mathrm{~s} / \mathrm{d} 1.000 .000$ & 3 \\
$1.000 .000 \mathrm{~s} / \mathrm{d} 1.500 .000$ & 2 \\
$>1.500 .000$ & 1 \\
\hline
\end{tabular}

Selanjutnya, setelah bobot seluruh kriteria penilaian ditentukan, dilakukan proses perhitungan menggunakan model SAW dan WP. Di dalam penelitian ini kriteria jumlah tanggungan dan kepala keluarga merupakan atribut keuntungan, sedangkan kriteria kondisi rumah dan jumlah penghasilan merupakan atribut biaya.

\section{A. Skenario Uji Coba Simple Additive Weighting}

Berdasarkan data alternatif (Alt) pada Tabel 2 dan kriteria penilaian, rating kecocokan tiap alternatif pada seluruh kriteria ditampilkan pada Tabel 7.

\begin{tabular}{cccccc}
\multicolumn{7}{c}{ Tabel 7. Rating Kecocokan } \\
\hline Alt & C1 & C2 & C3 & C4 & C5 \\
\hline A1 & 4 & 4 & 1 & 1 & 2 \\
A2 & 4 & 3 & 4 & 3 & 4 \\
A3 & 1 & 1 & 1 & 3 & 4 \\
A4 & 3 & 2 & 1 & 1 & 3 \\
A5 & 4 & 3 & 1 & 3 & 3 \\
A6 & 4 & 4 & 1 & 1 & 2 \\
A7 & 4 & 3 & 1 & 1 & 3 \\
A8 & 4 & 3 & 1 & 1 & 3 \\
A9 & 3 & 2 & 1 & 3 & 3 \\
A10 & 3 & 2 & 1 & 3 & 3 \\
A11 & 4 & 3 & 1 & 3 & 3 \\
A12 & 1 & 1 & 4 & 3 & 4 \\
A13 & 4 & 3 & 1 & 1 & 2 \\
A14 & 3 & 2 & 1 & 3 & 3 \\
A15 & 2 & 2 & 4 & 3 & 4 \\
A16 & 4 & 3 & 1 & 1 & 3 \\
A17 & 1 & 1 & 1 & 3 & 4 \\
A18 & 2 & 2 & 1 & 1 & 3 \\
A19 & 1 & 1 & 4 & 3 & 4 \\
A20 & 2 & 1 & 1 & 3 & 4 \\
\hline
\end{tabular}

Pengambil keputusan memberikan bobot preferensi sebagai berikut: $\mathrm{W}=(20 \%, 20 \%, 20 \%, 20 \%, 20 \%)$. Prosentase bobot tersebut ditentukan berdasarkan hasil wawancara antara penulis dengan pihak pengurus desa Babakan. Tabel 8 menunjukkan hasil perankingan nilai preferensi tiap alternatif berdasarkan Persamaan (2).

Tabel 8. Perankingan Nilai Preferensi dengan Model SAW

\begin{tabular}{|c|c|c|}
\hline Alternatif & Hasil & Peringkat \\
\hline A2 & 0,95 & 1 \\
\hline A15 & 0,8 & 2 \\
\hline A5 & 0,75 & 3 \\
\hline A 11 & 0,75 & 4 \\
\hline A12 & 0,7 & 5 \\
\hline A19 & 0,7 & 5 \\
\hline A14 & 0,65 & 6 \\
\hline A9 & 0,65 & 7 \\
\hline A10 & 0,65 & 7 \\
\hline A1 & 0,6167 & 8 \\
\hline A16 & 0,6167 & 8 \\
\hline A6 & 0,6167 & 8 \\
\hline A7 & 0,6167 & 8 \\
\hline A8 & 0,6167 & 8 \\
\hline A20 & 0,6 & 9 \\
\hline A13 & 0,5667 & 10 \\
\hline A17 & 0,55 & 11 \\
\hline A3 & 0,55 & 11 \\
\hline A4 & 0,5167 & 12 \\
\hline A18 & 0,4667 & 13 \\
\hline
\end{tabular}

Berdasarkan perankingan nilai preferensi seluruh alternatif pada Tabel 8, terdapat beberapa alternatif memiliki nilai preferensi yang sama sehingga memperoleh nilai peringkat yang sama. Perbandingan antara hasil perhitungan pada aplikasi dan hasil perhitungan secara manual menunjukkan kesamaan, sehingga dapat disimpulkan bahwa algoritma Simple Additive Weighting berhasil diterapkan pada aplikasi.

\section{B. Skenario Uji Coba Weighted Product}

Pengambil keputusan memberikan bobot preferensi sebagai berikut: $\mathrm{W}=(20 \%, 20 \%, 20 \%$, $20 \%, 20 \%$ ). Prosentase bobot tersebut ditentukan 
berdasarkan hasil wawancara antara penulis dengan pihak pengurus desa Babakan. Tabel 9 menunjukkan nilai preferensi tiap alternatif berdasarkan Persamaan (3).

\begin{tabular}{cccccc}
\multicolumn{7}{c}{ Tabel 9. Nilai Preferensi } \\
\hline Alt & C1 & C2 & C3 & C4 & C5 \\
\hline A1 & 1,3195 & 1,3195 & 1 & 1 & 1,1487 \\
A2 & 1,3195 & 1,2457 & 1,3195 & 1,2457 & 1,3195 \\
A3 & 1 & 1 & 1 & 1,2457 & 1,3195 \\
A4 & 1,2457 & 1,1487 & 1 & 1 & 1,2457 \\
A5 & 1,3195 & 1,2457 & 1 & 1,2457 & 1,2457 \\
A6 & 1,3195 & 1,3195 & 1 & 1 & 1,1487 \\
A7 & 1,3195 & 1,2457 & 1 & 1 & 1,2457 \\
A8 & 1,3195 & 1,2457 & 1 & 1 & 1,2457 \\
A9 & 1,2457 & 1,1487 & 1 & 1,2457 & 1,2457 \\
A10 & 1,2457 & 1,1487 & 1 & 1,2457 & 1,2457 \\
A11 & 1,3195 & 1,2457 & 1 & 1,2457 & 1,2457 \\
A12 & 1 & 1 & 1,3195 & 1,2457 & 1,3195 \\
A13 & 1,3195 & 1,2457 & 1 & 1 & 1,1487 \\
A14 & 1,2457 & 1,1487 & 1 & 1,2457 & 1,2457 \\
A15 & 1,1486 & 1,1487 & 1,3195 & 1,2457 & 1,3195 \\
A16 & 1,3195 & 1,2457 & 1 & 1 & 1,2457 \\
A17 & 1 & 1 & 1 & 1,2457 & 1,3195 \\
A18 & 1,1486 & 1,1487 & 1 & 1 & 1,2457 \\
A19 & 1 & 1 & 1,3195 & 1,2457 & 1,3195 \\
A20 & 1,1486 & 1 & 1 & 1,2457 & 1,3195 \\
\hline
\end{tabular}

Setelah proses perhitungan nilai preferensi tiap alternatif usai, selanjutnya dilakukan perhitungan nilai preferensi relatif yang digunakan untuk melakukan perankingan tiap alternatif. Tabel 10 menunjukkan hasil perhitungan dan perankingan nilai preferensi relatif seluruh alternatif.

\begin{tabular}{ccc}
\multicolumn{2}{c}{ Tabel 10. Perankingan Nilai Preferensi dengan Model WP } \\
\hline Alternatif & Hasil & Peringkat \\
\hline A2 & 0,0826 & 1 \\
A15 & 0,0663 & 2 \\
A11 & 0,0591 & 3 \\
A5 & 0,0591 & 3 \\
A14 & 0,0514 & 4 \\
A10 & 0,0514 & 4 \\
A9 & 0,0514 & 4 \\
A12 & 0,0502 & 5 \\
A19 & 0,0502 & 5 \\
A7 & 0,0474 & 6 \\
A8 & 0,0474 & 6 \\
A16 & 0,0474 & 6 \\
A1 & 0,0463 & 7 \\
A6 & 0,0463 & 7 \\
A20 & 0,0437 & 8 \\
A13 & 0,0437 & 8 \\
A4 & 0,0413 & 9 \\
A17 & 0,0381 & 10 \\
A18 & 0,0381 & 10 \\
A3 & 0,0381 & 10 \\
& &
\end{tabular}

Berdasarkan perankingan nilai preferensi seluruh alternatif pada Tabel 10, terdapat beberapa alternatif memiliki nilai preferensi yang sama sehingga memperoleh nilai peringkat yang sama. Perbandingan antara hasil perhitungan pada aplikasi dan hasil perhitungan secara manual menunjukkan kesamaan, sehingga dapat disimpulkan bahwa algoritma Weighted Product berhasil diterapkan pada aplikasi.

\section{KESIMPULAN DAN SARAN}

Hasil pengujian Blackbox menunjukkan bahwa seluruh fitur aplikasi dapat berfungsi dengan baik, algoritma SAW dan WP berhasil diimplementasikan ke dalam aplikasi, sehingga dapat disimpulkan bahwa aplikasi memiliki performa yang baik untuk memberikan rekomendasi penerima Rastra. Pada skenario hasil pengujian SAW dan WP, tampak bahwa algoritma SAW mampu memberikan hasil yang lebih baik daripada WP. Hal ini terlihat dari jumlah peringkat alternatif yang muncul dari hasil perhitungan yakni sejumlah 13 peringkat, berbeda dengan WP yang hanya mampu menampilkan 10 peringkat. Semakin banyak jumlah peringkat yang muncul dari hasil perhitungan semakin baik, karena algoritma tersebut terbukti mampu meminimalisir nilai preferensi yang sama, sehingga perankingan alternatif dapat dilakukan dengan baik.

Pada penelitian berikutnya, kami akan mengidentifikasi parameter/kriteria lain yang berpotensi diikutsertakan dalam proses perhitungan. Identifikasi parameter baru ini untuk meminimalisir hasil perhitungan nilai preferensi yang sama, sehingga perankingan alternatif dapat dilakukan dengan jelas. Selain itu, pada penelitian berikutnya, kami akan menggunakan model MADM yang lain, seperti ELECTRE, TOPSIS, dan AHP untuk melakukan perhitungan dalam menentukan rekomendasi penerima Rastra. Penggunaan beberapa model tersebut bermaksud untuk menganalisis performa masing-masing model dalam menentukan nilai preferensi dan melakukan perankingan alternatif.

\section{DAFTAR PUSTAKA}

AHMADI, A., \& WIYANTI, D.T., 2014. Implementasi Weighted Product (WP) dalam Penentuan Penerima Bantuan Langsung Masyarakat PNPM Mandiri Perdesaan. Seminar Nasional Aplikasi Teknologi Informasi (SNATI), p. A-19 A-22. Yogyakarta: Universitas Islam Indonesia.

BATU, J.A.J.L., \& FIBRIANI, C., 2017. Analisis Penentuan Lokasi Evakuasi Bencana Banjir dengan Pemanfaatan Sistem Informasi Geografis dan Metode Simple Additive Weighting (Studi Kasus : Kota Surakarta). Jurnal Teknologi Informasi dan Ilmu Komputer (JTIIK), 4(2), p. 127-135. Malang: Universitas Brawijaya.

BISWAS, P., PRAMANIK, S., \& GIRI, B.C., 2015. TOPSIS Method For Multi-Attribute Group Decision-Making Under Single-Valued Neutrosophic Environment. Neural Computing and Applications, 27(3), p. 727-737. London: SPRINGER.

DING, T., LIANG, L., YANG, M., \& WU, H., 2016. Multiple Attribute Decision Making 
Based On Cross-Evaluation With Uncertain Decision Parameters. Mathematical Problems in Engineering, 2016(2016), p. 110. London: Hindawi Publishing Corporation.

DIVAYANA, D.G.H., ADIARTA, A., \& ABADI, I.B.G.S., 2017. Conceptual And Physical Design Of Evaluation Program For Optimizing Digital Library Services At Computer College In Bali Based On CseUcla Model Modification With Weighted Product. Journal of Theoretical and Applied Information Technology, 95(16), p. 37673782. Islamabad: Little Lion Scientific.

HANDAYANI, T.P., 2017a. Analisa Penentuan Perubahan Calon Penerima Rastra (Beras Sejahtera) dengan Metode Simple Additive Method (SAW) di Desa Huidu Kabupaten Gorontalo. Jurnal Nasional Informatika dan Teknologi Jaringan, 2(1), p. 22-26. Medan: Universitas Islam Sumatera Utara.

HANDAYANI, T.P., 2017b. Penentuan Perubahan Calon Penerima Rastra (Beras Sejahtera) di Desa Huidu Menggunakan Metode Weight Product. Jurnal Masyarakat Informatika Indonesia, 2(3). Bandung: KOMUNIKA INFORMATIKA.

HASUGIAN, P.S., HUTAHAEAN, H.D., \& SIHOTANG, H.T., 2017. Sistem Pendukung Keputusan Penentuan Guru Wali Kelas Pada SMP Negeri 19 Medan dengan Menggunakan Metode Simple Additive Weighting. Journal Of Informatic Pelita Nusantara, 2(1), p. 32-39. Medan: STMIK Pelita Nusantara.

HIDAYAT, M., \& BAIHAQI, M.A.M., 2016. Sistem Pendukung Keputusan untuk Pemilihan Hotel dengan Simple Additive Weighting (Saw) Berbasis Web. Seminar Nasional Teknologi Informasi dan Multimedia 2016, p. 3.3-61 - 3.3-66. Yogyakarta: STMIK AMIKOM Yogyakarta.

KHAIRUL, SIMAREMARE, M., \& SIAHAAN, A.P.U., 2016. Decision Support System in Selecting The Appropriate Laptop Using Simple Additive Weighting. International Journal of Recent Trends in Engineering \& Research, 2(12), p. 215-222. Bhavnagar: IJRTER.

MULYANI, E.D.S., SUGIHARTO, A., \& AGUSTIAN, R., 2016. Penyeleksian Siswa Partner Schulen Der Zukunft dengan Metode Weighted Product (WP) di SMAN 3 Tasikmalaya. Creative Information Technology (CITEC) Journal, 3(4), p. 319330. Yogyakarta: Universitas AMIKOM Yogyakarta.
MUSLIHUDIN, M., \& ARUMITA, A.W., 2016. Pembuatan Model Penilaian Proses Belajar Mengajar Perguruan Tinggi Menggunakan Fuzzy Simple Additive Weighting (Studi : STMIK Pringsewu). Seminar Nasional Teknologi Informasi dan Multimedia 2016, p. 4.11-31 - 4.11-36. Yogyakarta: STMIK AMIKOM Yogyakarta.

PANDEAN, S.S., \& HANSUN, S., 2018. Aplikasi Web untuk Rekomendasi Restoran Menggunakan Weighted Product. Jurnal Teknologi Informasi dan Ilmu Komputer (JTIK), 5(1), p. 87-94. Malang: Universitas Brawijaya.

RAMADHAN, A., NINGRUM, I.P., \& YAMIN, M., 2016. SIASET Fakultas Teknik Universitas Halu Oleo dengan Menggunakan Sistem Penunjang Keputusan Metode Weighted Product dan Sistem Informasi Geografis Berbasis Web. semanTIK, 2(2), p. 65-74. Kendari: Universitas Halu Oleo.

RAMADHANI, S.F., HIDAYAT, N., \& SUPRAPTO, 2018. Sistem Pendukung Keputusan Rekomendasi Pemberian Usaha Kredit Mikro (UKM) dengan Metode AHPSAW (Study Kasus: PD. BPR Bojonegoro). Jurnal Pengembangan Teknologi Informasi dan Ilmu Komputer, 2(8), p. 2620-2627. Malang: Universitas Brawijaya.

SIAGIAN, I., SULINDAWATY, \& SINAGA, B., 2017. Sistem Pendukung Keputusan Pemilihan Asuransi dengan Metode Weighted Product dan Weighted Sum Model Pada PT. PRUDENTIAL. Jurnal Manajemen Dan Informatika Pelita Nusantara, 1(2), p. 59-64. Medan: STMIK Pelita Nusantara Medan.

WATI, R., \& MAYASARI, E., 2015. Sistem Pendukung Keputusan Pemilihan Bibit Sapi Unggul dengan Metode Simple Additive Weighting (SAW) Pada Peternakan Sapi Sriagung Padangratu Lampung Tengah. Jurnal TAM (Technology Acceptance Model), 5, p. 22-28. Lampung: STMIK Pringsewu Lampung.

WULANDARI, MUSTOFA, A., PONIDI, MUSLIHUDIN, M., \& FIRDIANSAH, F.A., 2016. Decision Support System Pemetaan Lahan Pertanian yang Berkualitas untuk Meningkatkan Hasil Produksi Padi Menggunakan Metode Simple Additive Weighting (SAW). Seminar Nasional Teknologi Informasi dan Multimedia 2016, p. 1.3-19 - 1.3-24. Yogyakarta: STMIK AMIKOM Yogyakarta. 